\title{
TU/e emonownen

\section{Analysis and design of a slotless tubular permanent magnet actuator for high acceleration applications}

\section{Citation for published version (APA):}

Meessen, K. J., Paulides, J. J. H., \& Lomonova, E. A. (2009). Analysis and design of a slotless tubular permanent magnet actuator for high acceleration applications. Journal of Applied Physics, 105(7), 07F110-1/3. [07F110]. https://doi.org/10.1063/1.3072773

DOI:

10.1063/1.3072773

Document status and date:

Published: 01/01/2009

\section{Document Version:}

Publisher's PDF, also known as Version of Record (includes final page, issue and volume numbers)

\section{Please check the document version of this publication:}

- A submitted manuscript is the version of the article upon submission and before peer-review. There can be important differences between the submitted version and the official published version of record. People interested in the research are advised to contact the author for the final version of the publication, or visit the $\mathrm{DOI}$ to the publisher's website.

- The final author version and the galley proof are versions of the publication after peer review.

- The final published version features the final layout of the paper including the volume, issue and page numbers.

Link to publication

\section{General rights}

Copyright and moral rights for the publications made accessible in the public portal are retained by the authors and/or other copyright owners and it is a condition of accessing publications that users recognise and abide by the legal requirements associated with these rights.

- Users may download and print one copy of any publication from the public portal for the purpose of private study or research.

- You may not further distribute the material or use it for any profit-making activity or commercial gain

- You may freely distribute the URL identifying the publication in the public portal.

If the publication is distributed under the terms of Article 25fa of the Dutch Copyright Act, indicated by the "Taverne" license above, please follow below link for the End User Agreement:

www.tue.nl/taverne

Take down policy

If you believe that this document breaches copyright please contact us at:

openaccess@tue.nl

providing details and we will investigate your claim. 


\title{
Analysis and design of a slotless tubular permanent magnet actuator for high acceleration applications
}

\author{
K. J. Meessen, ${ }^{\text {a) }}$ J. J. H. Paulides, ${ }^{\text {b) }}$ and E. A. Lomonova \\ Department of Electrical Engineering, Eindhoven University of Technology, Den Dolech 2, \\ 5612 AZ Eindhoven, The Netherlands
}

(Presented 14 November 2008; received 22 September 2008; accepted 27 November 2008; published online 3 March 2009)

This paper presents the design of a linear actuator for high acceleration applications. In the analysis, a slotless tubular permanent magnet actuator is modeled by means of semianalytical field solutions. Several slotless topologies are modeled and compared to achieve the highest acceleration. A design has been proposed and built, and measurements are conducted to verify the models. (C) 2009 American Institute of Physics. [DOI: 10.1063/1.3072773]

\section{INTRODUCTION}

In robotic applications there is an increasing demand for high-speed actuation with high precision and bandwidth capabilities. One particular application is the pick and place (P\&P) robot that places surface mounted devices (SMDs) on printed circuit boards, which are picked from a feeder. The complete $\mathrm{P} \& \mathrm{P}$ action requires four degrees of freedom robotic motion. However, this paper focuses on the shortstroke $(30 \mathrm{~mm})$ linear motion in the vertical direction to pick and place the components. To increase the current throughput of the total P\&P cycle, currently a maximum of 8000 components/h, a high acceleration level is necessary. ${ }^{1}$

This paper proposes a slotless tubular permanent magnet actuator (TPMA), as shown in Fig. 1, since it has a high force density, no end windings, and ideally a zero net radial attraction force between the translator and armature. The tubular actuator consists of a stator and a translator, where a moving magnet translator is preferred since it does not require winding connections to the moving part. To minimize all the disturbance (end effect, slot, etc.) cogging forces, the stationary part containing the three phase windings is slotless. Indeed a slotless topology still suffers from end-effect cogging forces, although considerably less than the slotted counterpart. Further, this disturbance force can be minimized by changing the shape of the stationary part. ${ }^{2}$ An additional advantage is the manufacturability of a slotless structure since the soft-magnetic stator part is simply a tube.

In order to have a design tool which facilitates both the waveform and the mean value of the force in a time-efficient way, semianalytical descriptions of the magnetic field distribution are derived. The main advantages over using finite element analysis to design an actuator are the time-efficient calculation of the field distribution and the ease of adding other physical behaviors, e.g., thermal, to these models to create a powerful and very fast multiphysical design tool.

\footnotetext{
${ }^{a)}$ Electronic mail: k.j.meessen@tue.nl.

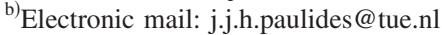

\section{SEMIANALYTICAL DESCRIPTION}

Several papers have been written on the design of tubular actuators using semianalytical field equations. In Refs. 3-5 semianalytical solutions for the magnetic fields in different tubular actuator topologies are presented, and Ref. 6 compares the force densities of three different topologies. Although these papers are very extensive, the conclusions from Ref. 6 cannot be used in this research as the force is maximized instead of the acceleration. These two quantities are strongly connected but show different optima. Therefore, the models described in these papers are reconsidered, extended, and used to perform an extended parametric study to obtain the highest TPMA translator acceleration.

\section{MAGNETIC LOADING}

First, the field due to the permanent magnets is described with a semianalytical formulation where the coils are modeled as air. Hence, the armature reaction field is not considered in the model. The formulation is obtained by solving the magnetostatic field equations using the magnetic vector potential $\mathbf{A}$, defined as

$$
\mathbf{B}=\nabla \times \mathbf{A},
$$

where $\mathbf{B}$ is the magnetic flux density. ${ }^{7}$ Due to the symmetry in the circumferential direction in tubular actuators, the magnetic flux density $\mathbf{B}$ has only an $r$ - and a $z$-component. Therefore, the magnetic vector potential has only a circumferential $\theta$-component and the vector potential can be treated like a scalar potential.

In the model, the following assumptions are made:

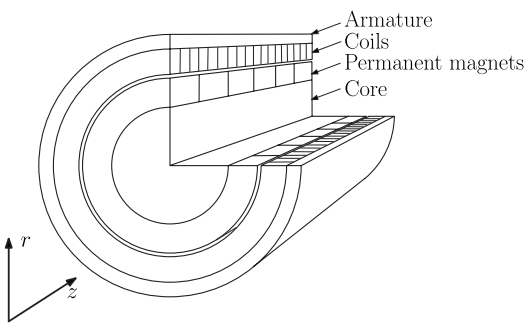

FIG. 1. A slotless TPMA. 
(1) The soft-magnetic parts are infinitely permeable.

(2) The actuator is infinitely long; the end effects are neglected.

(3) The permanent magnets have a linear demagnetization characteristic and are fully magnetized in the direction of magnetization.

Different regions have to be considered where in the source free regions (core, airgap, and coils; Fig. 1), the Laplace equation has been solved,

$$
\nabla^{2} \mathbf{A}=0
$$

and in the permanent magnet region, the Poisson equation has been solved,

$$
\nabla^{2} \mathbf{A}=-\mu_{0} \nabla \times \mathbf{M},
$$

where $\mathbf{M}$ is the magnetization vector describing the magnet array on the translator by a Fourier series. The solution for $\mathbf{B}$ is obtained by applying boundary conditions on the interfaces of the regions as described in Refs. 3-5.

\section{ELECTRICAL LOADING}

The electrical loading depends on the current density in the coils and the winding distribution. While the magnetic loading is primarily limited by material properties of the permanent magnet and the soft-magnetic material used in the armature and the translator, the electrical properties of the actuator are mainly restricted by thermal constraints. The current density in the coil region defines the heat produced due to dissipation in the windings. Due to this heat, the temperature difference between the armature and the ambient rises to

$$
\Delta T=J^{2} l_{\text {coil }} \rho_{\mathrm{Cu}}\left(R_{i}-\frac{l_{\text {coil }}}{2}\right) \frac{1}{k_{p} R_{s} h},
$$

where $J$ is the current density, $\rho_{\mathrm{Cu}}$ is the resistivity of copper, and $k_{p}$ is the packing factor of the coil region. In this expression, the coil and armature are assumed to be perfect heat conductors, which is a good approximation. ${ }^{8}$ The heat transfer coefficient varies from approximately $20 \mathrm{~W} \mathrm{~m}^{-2} \mathrm{~K}^{-1}$ for natural cooling up to $70 \mathrm{~W} \mathrm{~m}^{-2} \mathrm{~K}^{-1}$ when forced air cooling is used. ${ }^{9}$

\section{ACCELERATION}

Considering only the translator mass, which is a valid assumption in this application as the SMD components have a mass on the order of a few grams and the friction is neglected, the acceleration capability of the actuator is

$$
\mathbf{a}=\frac{\mathbf{F}}{m_{\mathrm{tr}}},
$$

where $m_{\mathrm{tr}}$ is the translator mass which has a linear dependency with the active length plus the stroke $(30 \mathrm{~mm}$ in this application), while the force $\mathbf{F}$ increases linearly with only the active length. A parametric search is performed with the semianalytical model of four different actuator topologies, viz.,

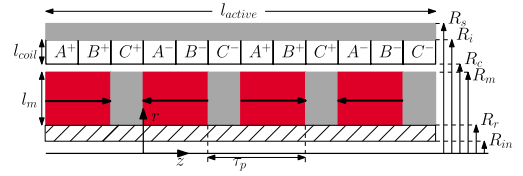

FIG. 2. (Color online) Axial magnetized slotless TPMA.

(1) radial magnetized topology,

(2) quasi-Halbach magnetized with soft-magnetic core,

(3) quasi-Halbach magnetized with nonmagnetic core, and

(4) axially magnetized topology.

The analysis showed that the quasi-Halbach topology is favorable when a small translator radius is used. Albeit that from manufacturing point of view, the axially magnetized topology is preferable, which is depicted in Fig. 2. This topology contains less permanent magnet material, and all magnets are magnetized in the (relatively easy) axial direction.

An important aspect in actuator design is efficiency. Therefore, a model is created where the current density is varied to maintain constant power dissipation in the coils. Figure 3 shows the results of the semianalytical model, where the pole pitch $\tau_{p}$, the magnet radius $R_{m}$, and the inner armature radius $R_{i}$ are varied. The numbers in the graph in Fig. 3 are calculated for a fixed $R_{i}=8.5 \mathrm{~mm}$, while the crosses show the optimal ratios independent of which value for $R_{i}$ is chosen. Using Eq. (4), the acceleration and force density levels are mainly limited by the achievable heat transfer coefficient (fixed to $20 \mathrm{~W} \mathrm{~m}^{-2} \mathrm{~K}^{-1}$ ) and the temperature constraint, i.e., maximum temperature rise of $40{ }^{\circ} \mathrm{C}$ for a duty cycle of $34 \%$. These constraints provide the allowable TPMA current density level. Further, in the design, the permanent magnet has a relative permeability of 1.05 and a remanent flux density of $1.15 \mathrm{~T}$; an airgap length of 0.25 $\mathrm{mm}, R_{\text {out }}=R_{i}+2.0 \mathrm{~mm}, R_{r}=2.0 \mathrm{~mm}$, an active length of $100.0 \mathrm{~mm}$, and $\alpha_{p}=0.725$ are considered. The solid translator core as shown in Fig. 1 is modeled as aluminum. The eddy currents in this core are very small, approximately $0.3 \mathrm{~mW}$, mainly caused by reluctance perturbations at the armature ends resulting in traveling spatial harmonics of the flux density.

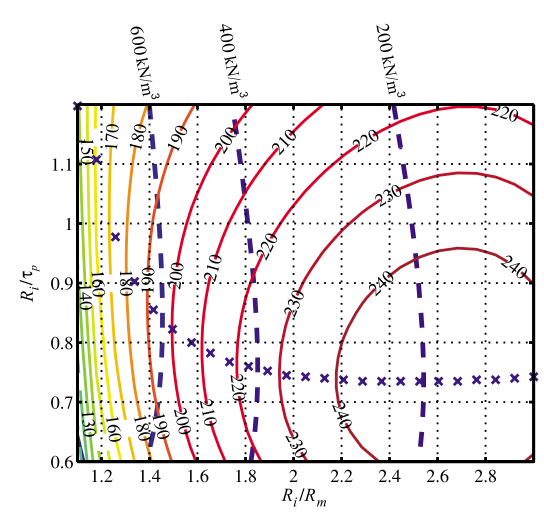

FIG. 3. (Color online) Acceleration (solid contour lines) of an axial magnetized TPMA vs $R_{i} / \tau_{p}$ and $R_{i} / R_{m}$. The dashed lines show the force density and the crosses show the optimal $R_{i} / \tau_{p}$ ratio for a certain value of $R_{i} / R_{m}$. The values in the figure are calculated for $R_{i}=8.5 \mathrm{~mm}$. 
TABLE I. Geometric parameters of four designs.

\begin{tabular}{lcccc}
\hline \hline Parameter & Design 1 & Design 2 & Design 3 & Design 4 \\
\hline$R_{m}(\mathrm{~mm})$ & 6.00 & 9.00 & 12.00 & 15.00 \\
$R_{i}(\mathrm{~mm})$ & 8.25 & 11.40 & 15.00 & 18.50 \\
$\tau_{p}(\mathrm{~mm})$ & 8.33 & 12.00 & 15.35 & 18.07 \\
$P_{\text {copper }}(\mathrm{W})$ & 5.3 & 6.8 & 8.7 & 10.2 \\
$a\left(\mathrm{~m} \mathrm{~s}^{-2}\right)$ & 193 & 150 & 138 & 121 \\
$F_{\text {dens }}\left(\mathrm{N} \mathrm{m}^{-3}\right)$ & $6.5 \times 10^{5}$ & $7.3 \times 10^{5}$ & $7.2 \times 10^{5}$ & $6.9 \times 10^{5}$ \\
$F(\mathrm{~N})$ & 21.5 & 41 & 65 & 91 \\
\hline \hline
\end{tabular}

Figure 3 clearly shows that a ratio of $R_{i} / R_{m}$ of approximately 2.6 results in the highest acceleration. This illustrates the favorability of a small translator radius to realize high acceleration levels, which in this particular example is $R_{m}$ $=3.2 \mathrm{~mm}$. However, the force density and the translator stiffness are much lower for this small translator radius. When larger translator radii are used, the reduced acceleration level can be improved by increasing the inner diameter of the core, $R_{\text {in }}$, to decrease the translator mass, although very high acceleration levels will always favor relatively small TPMA radii.

The analysis in this paper is extended to illustrate the influence of $R_{m}$ on the achievable acceleration and force density levels again limited by a maximum temperature rise of $40{ }^{\circ} \mathrm{C}$ at a $34 \%$ duty cycle. The analysis results are summarized in Table I for an active length of $100.0 \mathrm{~mm}$, an airgap length of $R_{c}-R_{m}=0.25 \mathrm{~mm}$, and a solid core with $R_{r}$ $=2.00 \mathrm{~mm}$. The results illustrate that, for example, doubling the translator diameter (designs 1 and 3 ) results in a $28 \%$ reduced acceleration level, a 10\% increased force density, and a $200 \%$ increased force level. Further, it is interesting to note that a clear optimum (design 2 ) exists when considering the force density levels. However this optimum cannot be identified for the acceleration level. This illustrates that the TPMA design is mainly bound by the applications necessary acceleration and force levels (also very dependent on payload) although Table I clearly illustrates the TPMA potential.

\section{MEASUREMENTS}

To verify the semianalytical models and assumptions, design 1, as given in Table I, is built, as shown in Fig. 4, and extended measurements are performed. For practical implementation, a small slit is introduced in the stator to terminate the windings, which gives a very small decrease in magnetic loading but limits the stator eddy currents in the solid back-

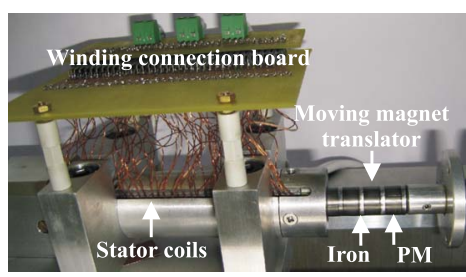

FIG. 4. (Color online) Prototype of an axial magnetized TPMA, design 1. iron. The application specific motion profile is used with stroke, acceleration, and peak velocity of $30.0 \mathrm{~mm}$, $200 \mathrm{~m} \mathrm{~s}^{-2}$, and $2.0 \mathrm{~m} \mathrm{~s}^{-1}$, respectively. The controller mainly contains acceleration, gravity compensation, and endeffect cogging (due to the finite length of the translator) feedforward. This combined with a position controller (closed loop bandwidth of approximately $280 \mathrm{~Hz}$ ) resulted in an error at the end of the motion profile of $4 \mu \mathrm{m}$.

\section{THERMAL TEST}

Static thermal tests have been performed to verify the heat transfer coefficient and the assumption that the winding temperature is equal to the actuators' outer surface. A constant power is applied to the actuator while the ambient surface of the actuator and the winding temperatures are measured until steady state $\left(1^{\circ} \mathrm{C} / 15 \mathrm{~min}\right)$ was achieved. Numerous thermal tests provided that only a small temperature drop of approximately $3{ }^{\circ} \mathrm{C}$ exists between the windings and the outer surface. Furthermore, the heat transfer coefficient appeared to be $25 \mathrm{~W} \mathrm{~m}^{-2} \mathrm{~K}^{-1}$ in the laboratory environment without forced cooling. This validated the use of Eq. (4) to determine the temperature rise of the TPMA.

\section{CONCLUSIONS}

Several TPMAs have been designed for high acceleration applications. This has been achieved by using fast and accurate analysis/design tools based on semianalytical field solution. Using these models, a parametric search on the achievable acceleration and force density by TPMAs is performed. From different topologies, a slotless actuator with axial magnetized translator is selected, mainly due to the smooth force characteristic and ease of manufacturability. A sample TPMA has been built and extensively tested, where acceleration and force density levels of $200 \mathrm{~m} \mathrm{~s}^{-2}$ and 9.1 $\times 10^{5} \mathrm{~N} \mathrm{~m}^{-3}$ have been achieved considering a maximum actuator surface temperature rise of $40{ }^{\circ} \mathrm{C}$ at a $34 \%$ duty cycle. The performance of this actuator is approximately three times higher than that of the currently used actuator in the application mentioned in Sec. I.

${ }^{1}$ J. J. H. Paulides, J. L. G. Janssen, and E. A. Lomonova, Proceedings of International Conference on Electrical Machines and Systems, 2008 (unpublished), p. 2954.

${ }^{2}$ J. Wang, M. Inoue, Y. Amara, and D. Howe, IEEE Trans. Magn. 152, 731 (2005).

${ }^{3}$ B. L. J. Gysen, E. A. Lomonova, J. J. H. Paulides, and A. J. A. Vandenput, IEEE Trans. Magn. 44, 1761 (2008).

${ }^{4}$ Jiabin Wang, Geraint W. Jewell, and David Howe, IEEE Trans. Magn. 35, 1986 (1999).

${ }^{5}$ S. M. Jang, J. Y. Choi, S. H. Lee, S. K. Cho, and W. B. Jang, Proceedings of the Sixth International Conference on Electrical Machines and Drives (2003) (unpublished), p. 250.

${ }^{6}$ J. Wang, G. W. Jewell, and D. Howe, IEE Proc.: Electr. Power Appl. 148, 456 (2001).

${ }^{7}$ E. P. Furlani, Permanent Magnet and Electromechanical Devices (Academic, San Diego, 2001).

${ }^{8}$ L. Encica, J. J. H. Paulides, E. A. Lomonova, and A. J. A. Vandenput, IEEE Trans. Ind. Appl. 44, 534 (2008).

${ }^{9}$ J. R. Hendershot and T. J. E. Miller, Design of Brushless Permanent Magnet Motors (Magna Physics, Oxford, 1994). 